\title{
Membrane phenotypic studies in B cell lymphoproliferative disorders
}

\author{
CS SCOTT, HJ LIMBERT, ID MACKARILL, BE ROBERTS
}

From the Department of Haematology, Regional Radiotherapy Centre, Cookridge Hospital, Leeds

SUMMARY A total of 398 cases of B cell lymphoproliferative disease were phenotypically characterised by membrane mouse red blood cell (MRBC) receptor, surface immunoglobulin, common acute lymphoblastic leukaemia (CALLA), and FMC7 and T1 monoclonal antibody studies. Relations between chronic lymphocytic leukaemia (CLL), prolymphocytic leukaemia (PLL), and "prolymphocytoid" CLL variants were examined with particular reference to the expression of FMC7. In addition, the reactivity of TU1 monoclonal antibody with B cell disorders was established. The results suggest that despite some heterogeneity most cases may be characterised by their phenotypic patterns and that these investigations provide a reproducible basis for classification.

Immunological studies in lymphoproliferative disease have been well documented. Although a greater understanding of the relation between phenotypic patterns and stages of cellular differentiation has been gained, the potential value of immunological characterisation is often limited by the small numbers of patients examined or the unavailability of some monoclonal reagents. One of the principal aims of phenotypic studies is to provide a fundamental basis for classifying lymphoproliferative disorders into prognostically relevant and reproducible groups. A prerequisite for such schemes is that the antisera used must be well characterised and widely available. Taking these factors into account, we reviewed the phenotypic patterns of B cell lymphoproliferative disorders referred to this department over the past two years and present here the results obtained with commercially available antisera for expression of surface immunoglobulin (SIg), common acute lymphoblastic leukaemia antigen (CALLA, J5), FMC7, TU1, and T1.

\section{Patients and methods}

\section{IMMUNOLOGICAL STUDIES}

Lymphocytes were fractionated from peripheral blood or bone marrow samples by density sedimentation with Lymphoprep (Nyegaard). Expression of membrane mouse red blood cell (MRBC) receptors

Accepted for publication 16 May 1985 was determined with CBA murine erythrocytes using standard procedures. ${ }^{12}$ Lymphocytes and MRBC were tested without first being treated with neuraminidase. The expression of SIg $\kappa$ or $\lambda$ light chains was investigated with polyclonal (Dako) or monoclonal (Unipath) reagents.

The fluorescent intensity of cells positive for SIg, considered to be an empirical measure of the membrane density was subjectively assessed in each case and scored negative, weak, weak to moderate, or moderate to strong. Studies of SIg were confined to showing the presence of light chain monoclonality and the establishment of membrane density. Investigations of the expression of heavy chain were not routinely performed owing to their apparent diagnostic inconsistency. ${ }^{3}$

The B nature of leukaemic cells was confirmed in all cases with the $B$ cell associated monoclonal antibodies Leu12 (antigenic determinant not established; Becton-Dickinson) or B1 (35k determinant, unclustered, Coulter). Other studies using conventional indirect immunofluorescence techniques with viable cells in suspension included CALLA/J5 (CD10 p100, Becton-Dickinson or Coulter), FMC7 (determinant not characterised, Sera Lab), TU1 (unknown determinant, Biotest-Folex), and T1 (CD5 p67, Dako). The T1 antibody (Clone DK23) used in this study detects a determinant, also recognised by Leul and OKT1, that is found on normal mature $T$ cells and is also present at lower density on malignant $B$ cells. ${ }^{4-6}$ The secondary antibody was an fluorescein isothiocyanate conjugated $\mathrm{Fab}_{2}$ goat antimouse immunoglobulin (Tago). 


\section{PATIENTS STUDIED}

Many of the cases examined were referred to this centre from various parts of the United Kingdom as part of the 1984 Leukaemia Research Fund data collection study. A common difficulty in studies of this type is that the categorisation of patients necessarily influences the interpretation of results.

Although morphological features of lymphoid cells are of some value, the acknowledged heterogeneity of lymphoproliferative disorders tends to limit the reproducibility of such classifications. If conventional morphological assessments are supplemented, however, by SIg density and MRBC receptor studies the resulting diagnostic categories are likely to have greater validity. We decided, therefore, to adopt certain generally accepted criteria ${ }^{12-11}$ for classifying patients in this study.

Cases categorised as chronic lymphocytic leukaemia (CLL) usually showed typical morphological features with insignificant nuclear clefting or nucleolation. In addition, the basic phenotype indicators considered to support this diagnosis were low monoclonal SIg density with significant $(>10 \%)$ expression of MRBC receptor. Cases of nonHodgkin's lymphoma often showed atypical morphological features - that is nuclear clefting-and phenotypically were characterised by increased monoclonal SIg densities and low expression of MRBC receptor.

Although the cases of non-Hodgkin's lymphoma could not be reliably classified further into centroblastic-centrocytic (CB-CC) or centrocytic types (unpublished observations), they were subdivided into two categories-namely, with $>10 \%$ CALLA positive cells; and those with no CALLA positive component. In cases of non-Hodgkin's lymphoma or CLL in which a discrepancy between morphological and immunological features occurred classification was decided on the basis of clinical findings.

Cases of prolymphocytic leukaemia (PLL) showed characteristic morphological features, moderate to strong SIg density and low expression of MRBC. A few (12) cases were also seen which morphologically showed appreciable nucleolation and phenotypically had lower SIg densities and higher expression of MRBC than seen in typical PLL. Clinical findings in these, however, were inconsistent with typical PLL and in some cases there was a history more in keeping with CLL. These cases were categorised as prolymphocytoid variants of chronic lymphocytic leukaemia (CLL-pro).

The small number of "hairy cell" leukaemias included in this study were classified on the basis of typical morphological, clinical, and cytochemical characteristics.

\section{Results}

EXPRESSION OF SIG LIGHT CHAIN

A total of 398 cases of B lymphoproliferation were examined with antisera specific for $\kappa$ or $\lambda$ light chains. Of the 295 cases of CLL (Table 1), 14 (5\%) were found to be SIg negative and 264 showed weak expression of SIg. Only 17 cases $(6 \%)$ classified as CLL by morphological and clinical criteria showed what was considered to be atypically increased (weak to moderate) SIg density.

Of the 77 cases of non-Hodgkin's lymphoma, 65 (84\%) were found to show moderate to strong monoclonal SIg expression, eight showed weak to moderate SIg density, and four were stained weakly. Among the patients with non-Hodgkin's lymphoma negative or positive for CALLA no differences were found in the incidence of SIg light chain types and no SIg negative cases were found.

Twenty six prolymphocytic leukaemias, comprising about $1 \%$ of cases examined, were observed during the study. Apart from the characteristic moderate to strong SIg density there was, in contrast to the groups with CLL and non-Hodgkin's lymphoma, a definite predominance of SIg- $\kappa$ positive cases (ratios $4 \cdot 20: 1)$. SIg densities in the 12 cases of CLL-pro were weak in nine and weak to moderate in two with the remaining case showing a mixture of mod? erate to strong $(20 \%)$ and weak positive cells.

EXPRESSION OF MEMBRANE MRBC RECEPTOR

A total of 396 cases were examined for expression of membrane MRBC receptors (Table 1). The proportion of cells positive for MRBC receptors was significantly higher in the group with CLL (mean $29.1 \%, \mathrm{n}=295$ ) compared with the group with non-Hodgkin's lymphoma (mean $8.8 \%, \mathrm{n}=75$ ) and that with PLL (mean $10.8 \%, n=26$ ). Furthermore, only $6 \%$ of cases of CLL showed $<10 \%$ positive cells in contrast to $77 \%$ and $73 \%$ for cases of nonHodgkin's lymphoma and PLL, respectively. All cases of CLL $(n=18)$ with $<10 \%$ MRBC receptor positive cells had low SIg densities. In contrast, of the 15 cases of non-Hodgkin's lymphoma with 10 $20 \%$ MRBC receptors, 14 showed moderate to strong SIg densities and only one (15\% rosettes) had weak expression of SIg. There were four cases of non-Hodgkin's lymphoma with MRBC receptors exceeding $20 \%$ (range $21-80 \%$ ), all of which had moderate SIg densities. The cases of CLL-pro showed a mean of $22.8 \%$ MRBC positive cells with an observed range of 5-55\%. Expression of MRBC by "hairy cell" leukaemia cells was low in the few examined (mean $4 \cdot 2 \%, n=11$ ), with 10 cases showing $<10 \%$ positive. 
Table 1 Analysis of SIg light chain and MRBC receptor expression in B cell lymphoproliferations

\begin{tabular}{|c|c|c|c|c|c|c|c|}
\hline $\begin{array}{l}\text { Diagnostic } \\
\text { category }\end{array}$ & $\begin{array}{l}\text { No in SIg } \\
\text { studies }\end{array}$ & SIg $\kappa$ positive & SIg $\lambda$ positive & $\kappa: \lambda$ ratio & SIg negative cases & $\begin{array}{l}\text { No in } M R B C \\
\text { studies }\end{array}$ & $\begin{array}{l}\operatorname{Mean}(S E) \\
M R B C(\%)\end{array}$ \\
\hline \multirow{3}{*}{$\begin{array}{l}\text { Chronic lymphocytic } \\
\text { leukaemia (CLL) } \\
\text { Non-Hodgkin's } \\
\text { lymphoma** } \\
\text { Prolymphocytic leu- } \\
\text { kaemia (PLL)*** }\end{array}$} & 295 & 168 & 113 & $1 \cdot 49: 1$ & 14 & 295 & $29 \cdot 1(0 \cdot 8)$ \\
\hline & 77 & 48 & 29 & $1 \cdot 65: 1$ & 0 & 75 & $8.8(1.5)$ \\
\hline & 26 & 21 & 5 & $4 \cdot 20: 1$ & 0 & 26 & $10.8(4.6)$ \\
\hline
\end{tabular}

*SIg density weak in 264/281 cases.

${ }^{*}$ * SIg density weak in four cases, weak to moderate in eight cases, and moderate to strong in 65 cases.

***Sig density moderate to strong in all cases.

MRBC = mouse red blood cells.

EXPRESSION OF THE CALLA (J5) DETERMINANT A total of 269 cases were examined (Table 2). Expression of the CALLA determinant, when present, was much weaker than that seen in common acute lymphoblastic leukaemia (C-ALL). Only one case of CLL out of 173 examined showed a slight increase $(12 \%)$ in CALLA positive cells whereas 35 of $77(45 \%)$ cases of non-Hodgkin's lymphoma, including one with weak SIg density, showed a significant $(>10 \%)$ CALLA positive component. Expression of CALLA was insignificant in 19 cases of PLL, and only one out of 12 of the cases of CLL-pro showed a slight increase (14\%) in weak positive cells.

\section{MEMBRANE EXPRESSION OF TU1 AND T1}

\section{DETERMINANTS}

Membrane expression of the $\mathrm{T} 1$ determinant was examined in 280 cases (Table 3 ). Its expression by leukaemic B cells was generally weak, although coexisting $T$ cells showed stronger membrane staining.

In the group with CLL 202 out of 211 (96\%) cases showed high proportions of weak $\mathrm{T} 1$ positive cells, two cases showed stronger expression of $\mathrm{T} 1$, while only seven ( $3 \%$ ) were $T 1$ negative. In the group with non-Hodgkin's lymphoma 32 of 47 (68\%) were T1 positive with a slightly higher proportion of $\mathrm{T} 1$ positive cases in the CALLA negative group (77\%) compared with CALLA positive cases (57\%). Of the 22 PLL cases, 15 (68\%) showed significant $\mathrm{T} 1$ expression, and all cases of CLL-pro were $\mathrm{T} 1$ positive.
A total of 242 cases of B lymphoproliferation were examined for expression of the TU1 determinant (Table 4). Of the 175 cases of CLL, 157 showed high proportions $(>70 \%)$ of positive cells. The expression of TU1 in these cases was usually weak, although $28(16 \%)$ cases showed stronger staining. Of the remaining cases, 17 showed a small but significant proportion of weak positive cells and only one case was found to be unreactive. In contrast, 25 out of 42 of the cases of non-Hodgkin's lymphoma were negative. When these cases were further subdivided into subgroups defined by CALLA it was found that $72 \%$ of the CALLA negative cases were TU1 negative compared with $41 \%$ for the CALLA positive lymphomas.

In the group with PLL 12 of 18 were TU1 negative. This was in contrast to the CLL-pro variants, which all expressed TU1. Only seven cases of "hairy cell" leukaemia were examined in this part of the study; all were TU1 negative.

The presence of membrane TU1 and T1 determinants in non-Hodgkin's lymphoma was further evaluated with regard to expression of CALLA and FMC7. In this analysis 54 cases of non-Hodgkin's lymphoma were subdivided into the following subgroups: CALLA negative and FMC7 negative; CALLA positive and FMC7 negative; CALLA negative and FMC7 positive; and CALLA positive and FMC7 positive. When the expression of TU1 and $\mathrm{T} 1$ was examined in these phenotypic groups (Table 5) no consistent pattern emerged, although the CALLA negative and FMC7 positive cases showed the lowest TU1 expression (three out of 21

Table 2 Analysis of CALLA (J5) expression by leukaemic cells in B cell lymphoproliferations

\begin{tabular}{|c|c|c|c|c|}
\hline \multirow[t]{2}{*}{ Diagnostic category } & \multirow[t]{2}{*}{ No of cases tested } & \multicolumn{3}{|c|}{$\%$ of positive cells } \\
\hline & & $<10$ & $10-50$ & $>50$ \\
\hline $\begin{array}{l}\text { Chronic lymphocytic leukaemia } \\
\text { Non-Hodgkin's lymphoma } \\
\text { Prolymphocytic leukaemia }\end{array}$ & $\begin{array}{r}173 \\
77 \\
19\end{array}$ & $\begin{array}{l}172^{*} \\
42^{* *} \\
19\end{array}$ & $\begin{array}{l}1 \\
23 * * * \\
0\end{array}$ & $\begin{array}{r}0 \\
12 \\
0\end{array}$ \\
\hline
\end{tabular}

*Includes 10 cases with SIg density increased above that seen in most cases of chronic lymphocytic leukaemia.

* Includes three cases with weak SIg density.

*** Includes one case with weak SIg density.

CALLA expression, when seen, was invariably weak. 
Table 3 Analysis of $T 1$ expression by leukaemic cells in B cell lymphoproliferations

\begin{tabular}{llll}
\hline Diagnostic category & \multicolumn{2}{l}{ Pattern of reaction } & \\
\cline { 2 - 4 } & Negative & Most cells weak positive & Most cells moderate to strong positive \\
\hline Chronic lymphocytic leukaemia $(\mathrm{n}=211)$ & 7 & 202 & 2 \\
Non-Hodgkin's lymphoma: & 15 & 28 & 4 \\
All cases $(\mathrm{n}=47)$ & 9 & 10 & 2 \\
CALLA positive $(\mathrm{n}=21)$ & 6 & 18 & 2 \\
CALLA negative $(\mathrm{n}=26)$ & 7 & 13 & 2 \\
Prolymphocytic leukaemia $(\mathrm{n}=22)$ &
\end{tabular}

Table 4 Analysis of TU1 expression by leukaemic cells in B cell lymphoproliferations

\begin{tabular}{lllll}
\hline Diagnostic category & \multicolumn{2}{l}{ Pattern of reaction } & & \\
\cline { 2 - 5 } & Negative & $\begin{array}{l}\text { Few cells weak } \\
\text { positive }\end{array}$ & $\begin{array}{l}\text { Most cells weak } \\
\text { positive }\end{array}$ & $\begin{array}{l}\text { Most cells moderate } \\
\text { to strong positive }\end{array}$ \\
\hline Chronic lymphocytic leukaemia $(\mathrm{n}=175)$ & 1 & 17 & 129 & 28 \\
Non-Hodgkin's lymphoma: & 25 & 4 & 8 & 5 \\
All cases $(\mathrm{n}=42)$ & 7 & 2 & 5 & 3 \\
CALLA positive $(\mathrm{n}=17)$ & 18 & 2 & 3 & 2 \\
CALLA negative $(\mathrm{n}=25)$ & 12 & 0 & 5 & 1 \\
Prolymphocytic leukaemia $(\mathrm{n}=18)$ & 7 & 0 & 0 & 0 \\
"Hairy cell" leukaemia $(\mathrm{n}=7)$ & & & & \\
\hline
\end{tabular}

cases with positive cells) and CALLA negative and FMC7 negative cases the highest expression of $\mathrm{T} 1$ ( 11 of 14 cases with positive cells). The frequency of T1 positive and TU1 positive, T1 negative and TU1 positive, T1 positive and TU1 negative, and T1 negative and TU1 negative phenotypic patterns in the cases of non-Hodgkin's lymphoma $(n=34)$ was found to be $38 \%, 15 \%, 23 \%$, and $24 \%$, respectively.

\section{EXPRESSION OF THE FMC7 DETERMINANT}

Expression of membrane FMC7 was examined in 247 cases (Table 6). Of the 150 cases of CLL, 121 $(81 \%)$ showed $<10 \%$ (weak) positive cells. Of the remaining 29 cases, 11 (all of which had weak SIg density) showed $10-20 \%$ weak positive cells; four (two of which showed atypically increased SIg density) showed 10-20\% moderate to strong FMC7 positive cells; nine (two with increased SIg density) had $>20 \%$ weak positive cells; and only five (low SIg density) showed $>20 \%$ moderate to strong positive cells. These five cases did not have a significant "prolymphocytic component" when examined morphologically.

Of the 55 cases of non-Hodgkin's lymphoma examined, $37(67 \%)$ showed in excess of $10 \%$ FMC7 positive cells. In 29 of these the FMC7 determinant was expressed with moderate to strong density. Analysis of the CALLA positive and CALLA negative subgroups of non-Hodgkin's lymphoma showed no significant correlation with expression of FMC7.

In the 28 cases of PLL studied 25 showed significant FMC7 positive components, two showed weak expression by $17 \%$ and $70 \%$ of cells, respectively, while the remaining case was FMC7 negative. All 14 cases of "hairy cell" leukaemia examined over the same period had high proportions of cells which expressed the FMC7 determinant strongly. FMC7 was also strongly expressed in five out of 12 $(>80 \%)$ positive cells) of the group with CLL-pro. Of the remaining cases, five showed $30-73 \%$ weak to moderate positive cells, one showed $21 \%$ weak to positive cells, and the other was FMC7 negative.

Table 5 Expression of TU1 and T1 determinants by leukaemic cells in 54 cases of non-Hodgkin's lymphoma grouped according to patterns of reaction of CALLA and FMC7

\begin{tabular}{|c|c|c|c|c|}
\hline & $\begin{array}{l}\text { CALLA negative } \\
F M C 7 \text { negative }\end{array}$ & $\begin{array}{l}\text { CALLA positive } \\
\text { FMC7 negative }\end{array}$ & $\begin{array}{l}\text { CALLA negative } \\
F M C 7 \text { positive }\end{array}$ & $\begin{array}{l}\text { CALLA positive } \\
\text { FMC7 positive }\end{array}$ \\
\hline $\begin{array}{l}\text { No of cases } \\
\% \text { of cases of non-Hodgkin's lymphoma examined } \\
\text { No of cases with TU1 positive cells } \\
\text { No of cases with T1 positive cells }\end{array}$ & $\begin{array}{l}14 \\
26 \% \\
6 \\
11\end{array}$ & $\begin{array}{l}9 \\
17 \% \\
7 \\
6\end{array}$ & $\begin{array}{l}21 \\
39 \% \\
3 \\
9\end{array}$ & $\begin{array}{l}10 \\
18 \% \\
6 \\
3\end{array}$ \\
\hline
\end{tabular}

* CALLA positive cases defined as those showing $>10 \%$ positive (weak) cells.

FMC7 positive cases defined as those showing $>10 \%$ positive (moderate to strong) cells. 
Table 6 Analysis of expression of FMC7 by leukaemic cells in B cell lymphoproliferations

\begin{tabular}{|c|c|c|c|c|}
\hline \multirow[t]{2}{*}{ Diagnostic category } & \multicolumn{4}{|c|}{ Pattern of reaction } \\
\hline & $\begin{array}{l}<10 \% \text { positive } \\
\text { cells }\end{array}$ & $\begin{array}{l}10-20 \% \text { weak to } \\
\text { moderate positive }\end{array}$ & $\begin{array}{l}>20 \% \text { weak } \\
\text { positive }\end{array}$ & $\begin{array}{l}>20 \% \text { moderate to } \\
\text { strong positive }\end{array}$ \\
\hline $\begin{array}{l}\text { Chronic lymphocytic leukaemia }(n=150) \\
\text { Non-Hodgkin's lymphoma: }\end{array}$ & 121 & $15^{*}$ & $9^{* *}$ & 5 \\
\hline $\begin{array}{l}\text { All cases }(n=55) \\
\text { CALLA positive }(n=19) \\
\text { CALLA negative }(n=36) \\
\text { Prolymphocytic leukaemia }(n=28) \\
\text { "Hairy cell" leukaemia }(n=14)\end{array}$ & $\begin{array}{r}18 \\
7 \\
11 \\
1 \\
0\end{array}$ & $\begin{array}{l}5 \\
2 \\
3 \\
1 \\
0\end{array}$ & $\begin{array}{l}5 \\
1 \\
4 \\
1 \\
0\end{array}$ & $\begin{array}{r}27 \\
9 \\
18 \\
25 \\
14\end{array}$ \\
\hline
\end{tabular}

*Includes two cases with SIg density increased above that seen in most cases of chronic lymphocytic leukaemia.

**Includes two cases with increased SIg density.

\section{Discussion}

This study examined the phenotypic characteristics of leukaemic cells from a large number of B cell lymphoproliferative disorders. In studies such as this objectivity of case classification is of fundamental importance as data obtained without regard to diagnostic reproducibility are often misleading. In addition, creation of artificial case groups may suggest relations with phenotypic patterns that, in reality, do not exist.

Using the diagnostic criteria detailed earlier, expression of SIg was found to be weak or absent in $94 \%$ of the patients with CLL, with only 17 of 295 cases showing unusually increased SIg density. Only $5 \%$ (four out of 77) of cases of non-Hodgkin's lymphoma showed unexpectedly low SIg density while all cases of PLL were stained strongly. These studies further indicate that expression of CALLA by leukaemic $B$ cells is consistent with a diagnosis of non-Hodgkin's lymphoma $(>10 \%$ positive cells found in $45 \%$ of cases) rather than chronic, or prolymphocytic, leukaemia, which was predominantly unreactive. The finding of low density SIg in cases of non-Hodgkin's lymphoma may be explained by a recent report which described a small proportion of follicular lymphomas with reduced Ig synthesis ${ }^{12}$ and previous observations that related expression of CALLA to centroblastic-centrocytic (CB-CC) lymphomas with follicular, rather than diffuse, architecture..$^{13-18}$ Although only one of our four cases of non-Hodgkin's lymphoma with low SIg density and low expression of MRBC receptor $(0,1,8$, and $14 \%$ ) showed a significant $(41 \%)$ CALLA positive component, a separate study (Morgan et al, unpublished observations) of circulating malignant cell phenotypes in histologically diagnosed cases of follicular lymphoma showed only a small proportion with CALLA positive cells.

Four cases of non-Hodgkin's lymphoma, all with moderate SIg densities, were also found in this study with $>20 \%$ MRBC receptor positive cells.
Although MRBC receptors are usually associated with CLL, it is recognised that malignant cells in CB-CC lymphomas may also express the receptor ${ }^{18}$ and that CB-CC and CLL cells may share closer ontological relations than was previously thought. ${ }^{19}$

Expression of FMC7 by leukaemic B cells is of particular diagnostic importance. Although the nature of the FMC7 determinant has not been elucidated ${ }^{20}$ it is expressed by a small proportion of normal SIg positive lymphocytes ${ }^{21}$ as well as the lymphoid cells from most cases of B-PLL and "hairy cell" leukaemia.9 ${ }^{22-25}$ CLL cells, which are normally FMC7 negative, may be induced to express membrane FMC7 by phorbol esters or bacterial lipopolysaccharides, ${ }^{26} 27$ although it is considered that this induction may be unrelated to changes in the level of cellular differentiation or cell cycle state. ${ }^{20}$

This present study confirms an association between the expression of FMC7 and the PLL or "hairy cell" leukaemia lymphoproliferative disorders. In addition, 29 of $150(19 \%)$ cases of CLL were found to have significant FMC7 positive components. Of the 15 cases with 10-20\% weak to moderate positive cells, two had atypically increased SIg density. A further nine cases were found with $>20 \%$ weak expression of FMC7 and five with $>20 \%$ moderate to strong expression. Of the 55 cases of nonHodgkin's lymphoma examined for FMC7, about $67 \%$ showed $>10 \%$ positive cells, and in most of these cases the determinant was expressed strongly. In addition, there did not seem to be any relation between FMC7 and CALLA staining of nonHodgkin's lymphoma cells, indicating its independence from lymphoma type, a conclusion also reached by Collins et al. ${ }^{28}$

An early description of the "prolymphocytoid" CLL (CLL-pro) variant suggested that despite the morphological appearance of prolymphocytic cells the SIg density remained low. ${ }^{29}$ A later study of eight patients reported that the emerging prolymphocytic cells tended to show higher SIg densities 
while the small, presumably residual, CLL cells retained low SIg expression. ${ }^{30}$ In this present investigation we found that SIg was expressed at a similar and relatively low density by all cells, irrespective of the proportion of "prolymphocytes," in 11 of 12 patients. Only one case was found to show a mixture of weak and strong SIg positive cells and, interestingly, this was the only case in the group to show insignificant expression of FMC7. The proportions of nucleolated lymphoid cells in the 29 FMC7 positive cases of CLL were low whereas the cases of CLL-pro were morphologically characterised by increased "prolymphocytoid" components as well as significant membrane FMC7 expression (11 of 12 cases).

These findings may be clarified by examining the clinical features of these patients (study currently in progress), although it is possible that FMC7 positive cases with classical CLL morphology may represent an early stage of "CLL-prolymphocytoid transformation," an intermediate stage between CLL and CLL-pro. As cases of CLL-pro usually continue to express SIg at low density, increased MRBC receptors, and preservation of other phenotypic determinants such as T1 and TU1, a complete transition from CLL to prolymphocytic leukaemia may be unlikely.

The expression of TU1 and T1 determinants was also assessed in this study. The results show that TU1 and T1, although found on cells from most cases of CLL (99\% and $96 \%$ for TU1 and T1, respectively), showed different distributions in the other case groups. In addition, TU1, unlike T1, does not stain normal T cells. ${ }^{31}$ In PLL most cases lacked TU1 $(66 \%)$ and were T1 positive $(68 \%)$, and further analysis showed that when both characteristics were taken into account a TU1 positive and T1 positive phenotype was found in only $30 \%$ of patients with PLL. By contrast, the prolymphocytoid CLL variants were both TU1 and T1 positive. There does not seem to be general agreement about the expression of T1 in PLL. Although the variable expression found in our series was also found by Jansen et al. ${ }^{9}$ (three of seven patients expressed the T65 determinant), it is not supported by the consistent inability of RFA-1 (12 cases) to stain PLL cells. ${ }^{32}$

There are few reports of TU1 expression by leukaemic B cells. Stein et al observed that TU1 was expressed in 11 cases of CLL examined and was present in 10 of 15 cases of follicular (CB-CC) and one of 81 cases of centrocytic (CC) lymphoma. ${ }^{18}$ In another study all cases of CLL $(n=25)$ were found to be TU1 positive as were significant proportions of cells from patients with CB-CC lymphoma. ${ }^{31}$ In this study only one out of 175 cases of CLL was found to be unreactive. Expression of these determinants in non-Hodgkin's lymphoma were variable, although it is of interest that $72 \%$ of CALLA negative cases were TU1 negative and only $23 \%$ were T1 negative. An association between CALLA positive cases and the absence of $\mathrm{T} 1$ expression has been suggested previously,,$^{17} 1833$ although others have reported a variable expression of Leul/OKT1 positive cells in follicular lymphomas. ${ }^{34} 35$

In conclusion, the results of this study suggest that, even with a limited range of immunological investigations, some consistency in classification of disease may be attained. The phenotypic pattern represented by most cases of CLL was clearly shown to be: low density SIg; increased expression of MRBC receptors; the presence of membrane TU1, and, finally, the absence of significant CALLA and FMC7. In contrast, leukaemic B cells in cases of non-Hodgkin's lymphoma tended to show higher SIg density and low MRBC receptors. CALLA or FMC7 determinants, or both were expressed in a significant proportion of cases of non-Hodgkin's lymphoma, whereas TU1 and T1 seemed to be of less value. In cases of PLL SIg density was strong, MRBC receptor expression low, and FMC7 nearly always present on most cells; CALLA was invari ably absent, and the TU1 determinant was seen in only a few cases. The results further suggest that the lack of TU1 expression can be reasonably inter preted as being inconsistent with a diagnosis of CLE and that in cases otherwise phenotypically suggestive of CLL membrane FMC7 may be expressed both in the absence (? early CLL-pro) or presence (CLL-pro) of morphological "prolymphocytoid" components. The interesting possibility that expression of FMC7 does not simply reflect maturational state requires further study to establish the expression of FMC7 in relation to other "markers" of differentiation and to assess whether the presence of FMC7 positive malignant cells in CLL-pro and non-Hodgkin's lymphoma is associated with distinct clinical features, such as splenic enlargement.

We thank the many haematologists who referred samples for these studies during the past two years. We also acknowledge the support of the Leukaemia Research Fund.

\footnotetext{
References

' Catovsky D, Cherchi M, Okos A, Hegde U, Galton DAG. Mouse red-cell rosettes in B-lymphoproliferative disorders. $\mathrm{Br}$ J Haematol 1976;33:173-7.

${ }^{2}$ Forbes IJ, Zalewski PD. A subpopulation of human B lymphocytes that rosette with mouse erythrocytes. Clin Exp Immunol 1976;26:99-107.

${ }^{3}$ Ling NR. Immunoglobulin as a differentiation and clonal marker. J Immunol Methods 1983;65:1-25.
} 
4 Martin PJ, Hansen JA, Nowinski RC, Brown MA. A new human T-cell differentiation antigen: unexpected expression on chronic lymphocytic leukaemia cells. Immunogenetics 1980;11:429-39.

${ }^{5}$ Boumsell L, Coppin H, Pham D, et al. An antigen shared by a human $\mathrm{T}$ cell subset and $\mathrm{B}$ cell chronic lymphocytic leukemia cells: distribution on normal and malignant lymphoid cells. $J$ Exp Med 1980;152:229-34.

- Royston I, Majda JA, Baird SM, Meserve BL, Griffiths JC. Human T-cell antigens defined by monoclonal antibodies: the 65,000-dalton antigen of T-cells (T65) is also found on chronic lymphocytic leukemia cells bearing surface immunoglobulin. $J$ Immunol 1980;125:725-31.

7 Slease RB, Wistar R, Scher I. Surface immunoglobulin density on human peripheral blood mononuclear cells. Blood 1979;54:72-87.

${ }^{8}$ Galton DAG, MacLennan ICM. Clinical patterns in B lymphoid malignancy. Clin Haematol 1982;11:561-87.

` Jansen J, den Ottolander GJ, Schuit HRE, Waayer JLM, Hijmans W. Hairy cell leukemia: its place among the chronic B cell leukemias. Semin Oncol 1984;11:386-93.

${ }^{10}$ Aisenberg AC, Wilkes B. Lymphosarcoma cell leukaemia: the contribution of cell surface study to diagnosis. Blood 1976; 48:707-15.

" Galton DAG, Goldman JM, Wiltshaw E, Catovsky D, Henry K, Goldenberg GJ. Prolymphocytic leukaemia. Br J Haematol 1974;27:7-23.

12 Gregg EO, Al-Saffar N, Jones DB, Wright WH, Stevenson FK. Immunoglobulin negative follicle centre cell lymphoma. $\mathrm{Br} J$ Cancer 1984;50:735-44.

${ }^{13}$ Pesando JM, Ritz J, Lazarus H, Baseman-Costello S, Sallan S, Schlossman SF. Leukemia-associated antigens in ALL. Blood 1979;54:1240-8.

14 Anderson KC, Bates MP, Slaughenhoupt BL, Pinkus GS, Schlossman SF, Nadler LM. Expression of human B cellassociated antigens on leukemias and lymphomas: a model of human B cell differentiation. Blood 1984;63:1424-33.

15 Greaves MF, Hariri G, Newman RA, Sutherland DR, Ritter MA, Ritz J. Selective expression of the common acute lymphoblastic leukemia (gp100) antigen on immature lymphoid cells and their malignant counterparts. Blood 1983;61:628 39.

${ }^{16}$ Ritz J, Nadler LM, Bhan AK, Notis-McConarty J, Pesando JM, Schlossman SF. Expression of common acute lymphoblastic leukemia antigen (CALLA) by lymphomas of B-cell and T-cell lineage. Blood 1981;58:648-52.

17 Harris NL, Nadler LM, Bhan AK. Immunohistologic characterization of two malignant lymphomas of germinal center type (centroblastic/centrocytic and centrocytic) with monoclonal antibodies. Am J Pathol 1984;117:262-72.

${ }^{18}$ Stein H, Gerdes J, Mason DY. The normal and malignant germinal centre. Clin Haematol 1982;11:531-59.

${ }^{19}$ Caligaris-Cappio F, Janossy G. Surface markers in chronic lymphoid leukaemias of B cell type. Semin Haematol 1985;22:112.

${ }^{20}$ Zola H, Moore MA, Hohmann A, Hunter IK, Nikoloutsopoulos $A$, Bradley J. The antigen of mature human B cells detected by the monoclonal antibody FMC7: studies on the nature of the antigen and modulation of its expression. J Immunol 1984;133:321-6.

21 Brooks DA, Beckman IER, Bradley J, McNamara PJ, Thomas ME, Zola $H$. Human lymphocyte markers defined by antibodies derived from somatic cell hybrids. J Immunol 1981;126:1373-7.

22 Zola $\mathrm{H}$, Bradley JG, Brooks DA, et al. The human B cell lineage studied with monoclonal antibodies. In: Bernard A, Boumsel L, Dausset J, Milstein C, Schlossman SF, eds. Leukocyte typing. Berlin: Springer-Verlag, 1984:363-71.

${ }^{23}$ Worman DP, Brooks D, Hogg DA, Zola H, Beverley PCL, Cawley JC. The nature of hairy cells: a study with a panel of monoconal antibodies. Scand J Haematol 1983;20:223-7.

${ }^{24}$ Catovsky D, Cherchi M, Brooks D, Bradley J, Zola $\mathbf{H}$. Heterogeneity of B-cell leukemias demonstrated by the monoclonal antibody FMC7. Blood 1981;58:406-8.

${ }^{25}$ Melo JV, San Miguel JF, Moss VE, Catovsky D. The membrane phenotype of hairy cell leukemia: a study with monoclonal antibodies. Semin in Oncol 1984;11:381-5.

${ }^{26}$ Caligaris-Cappio F, Janossy G, Campana D, et al. Lineage relationship of chronic lymphocytic leukaemia and hairy cell leukaemia: studies with TPA. Leuk Res 1984;8:567-78.

${ }^{27}$ Robert KH, Juliusson G, Biberfeld P. Chronic lymphocytic leukaemia cells activated in vitro reveal cellular changes that characterise B-prolymphocytic leukaemia and immunocytoma. Scand J Haematol 1983;17:397-401.

${ }^{28}$ Collins RJ, Bunce IH, Clarke EC, et al. Malignant lymphoma: reactive with the monoclonal antibody FMC7. Pathology 1983;3:350-1.

${ }^{29}$ Enno A, Catovsky D, O'Brien M, Cherchi M, Kumaran TO, Galton DAG. 'Prolymphocytoid' transformation of chronic lymphocytic leukaemia. Br J Haematol 1979;41:9-18.

${ }^{30}$ Kjeldsberg MD, Marty J. Prolymphocytic transformation of chronic lymphocytic leukaemia. Cancer 1981; 48:2447-57.

31 Ziegler A, Stein H, Muller C, Wernet P. TU1: a monoclonal antibody defining a $B$ cell subpopulation-usefulness for the classification of non-Hodgkin's lymphomas. In: Knapp W, ed. Leukemia Markers. London: Academic Press, 1981:113-60.

s2 Gobbi N, Caligaris-Cappio F, Janossy G. Normal equivalent cells of $\mathrm{B}$ cell malignancies: analysis with monoclonal antibodies. $\mathrm{Br}$ $J$ Haematol 1983; 54:393-403.

${ }^{33}$ Saati TA, Laurent G, Caveriviere P, Rigal F, Delsol G. Reactivity of Leu1 and T101 monoclonal antibodies with B cell lymphomas (correlation with other immunological markers). Clin Exp Immunol 1984;58:631-8.

34 Burns BF, Warnke RA, Doggett RS, Rouse RV. Expression of a T-cell antigen (Leu1) by B-cell lymphomas. Am J Pathol 1983;113:165-71.

${ }^{35}$ Knowles DM, Halper JP, Azzo W, Wang CY. Reactivity of monoclonal antibodies Leu 1 and OKT1 with malignant human lymphoid cells. Correlation with conventional cell markers. Cancer 1983;52:1369-77.

Requests for reprints to: Dr CS Scott, Department of Haematology, Cookridge Hospital, Leeds LS16 6QB, England. 